\title{
Sem pai, sem mãe ${ }^{1}$
}

\section{Gustavo Belisário D’araújo Couto}

Universidade de Brasília, Distrito Federal, Brasil

DOI 10.11606/issn.2316-9133.v24i24p140-157

resumo Este artigo busca fazer uma análise de um capítulo do romance de Jorge Amado Capitães da Areia à luz das teorias do parentesco. A situação criada na obra entre as personagens Sem-Pernas e Dona Ester suscita uma discussão sobre o papel da criança nas relaçóes familiares e, mais especificamente, nas relaçóes de filiação. Pensando a família a partir da ótica da personagem criança, a filiação pode ser entendida pela chave bourdiesiana da estratégia ou pela chave maussiana da reciprocidade. Seja pela reciprocidade ou pela estratégia, a inegável agência da criança na constituição de relaçóes gera reflexôes interessantes sobre o que significa ser pai ou mãe. A escrita de Jorge Amado convida a pensar as categorias mãe e pai menos como um ser e mais como um tornar-se.

palavras-chave Família; Criança; Capitães da areia; Estratégia; Agência.

\section{Fatherless, motherless}

abstract This article analyzes a chapter of the novel written by Jorge Amado Capitães da Areia through the theories of kinship. The situation created in the work between the characters Sem-Pernas and Dona Ester raises a discussion about the role of children in family relations and, more specifically, in the relationship of sonship. Thinking family from the perspective of the child character, parentage can be understood by the Bourdieusian key of strategy or the Maussian key of reciprocity in the affection. Either by affection or strategy, the agency of the child in creating relations brings interesting reflections on what it means to be father or mother. The brilliant writing of Jorge Amado invites us to think the categories of mother and father like a becoming.

keywords Family; Child; Capitães da areia; Strategy; Agency. 
Sem pai, sem mãe, sem mestre. Tinham de si apenas a liberdade de correr as ruas. Jorge Amado

Muitas vezes, nos deparamos com uma forma sensível de expor o mundo que nos revela o que nenhuma outra teoria nos revelou. A literatura tem a grande capacidade de inspirar ideias, mobilizar análises e levantar questóes. Neste artigo, pretendo refazer perguntas que sempre estiveram presentes na antropologia partindo do capítulo "A família", do romance Capitáes da Areia, de Jorge Amado. Passados quase oitenta anos, o romance tem muito a ensinar sobre a situação ainda atual das crianças abandonadas.

Jorge Amado (1912-2001) escreveu Capitáes da Areia em 1937, durante um período conturbado da história do Brasil. O escritor teve contato com o movimento comunista na década de 1930 e filiou-se ao Partido Comunista do Brasil, sigla pela qual foi eleito deputado federal em 1945. No mesmo ano da publicação de Capitáes da Areia, seus livros foram queimados em praça pública de Salvador devido ao conteúdo político da obra. ${ }^{2} \mathrm{O}$ livro conta a história de um grupo de crianças, moradoras de um trapiche de Salvador, que ficam conhecidas em toda a cidade pela alcunha Capitáes da Areia. A história narra desde o abandono das famílias e a integração no bando das crianças até o tornar-se adulto de algumas personagens. Na história não existem pais ou Estado que exerçam autoridade em relação a elas. Ao longo de toda a obra, elas roubam, estupram e andam livremente pelas ruas, obedecendo apenas a Pedro Bala, liderança do grupo.

O livro é divido em três partes, e cada uma delas é dividida em capítulos. Na primeira, Jorge Amado apresenta as personagens do bando, suas características e as paisagens por onde transitam em Salvador. O leitor conhece Pedro Bala, Boa-Vida, Sem-Pernas, Professor, Pirulito, Volta Seca, Gato e outras crianças que formam os Capitães da Areia. A segunda parte da obra conta o ingresso da primeira menina no grupo: Dora. A menina se relaciona como mãe e irmá das crianças do Capitáes da Areia e passa a ser companheira de Pedro Bala. Na última parte do livro, Jorge Amado apresenta os destinos de algumas personagens ao se tornarem adultas e adultos. Neste artigo, me atentarei especificamente para um capítulo da primeira parte chamado "A família". O capítulo descreve a adoção de um dos Capitães da Areia, Sem-Pernas, por Dona Ester.

Muito se discute na antropologia sobre as potencialidades e limites do diálogo com a literatura. James Clifford (1986) argumenta contra uma distinção estanque entre literatura e ciência. Para o autor, poesia, arte e literatura não estáo limitadas ao subjetivismo. O fazer etnográfico pode aprender com a forma não representacional que a ficção consegue des- 
crever, sem perder determinada precisão e objetividade. Na mesma linha, chamando atenção para as possibilidades desse intercâmbio entre literatura e antropologia, Marine Corde (2013) ressalta que os limites entre subjetividade e objetividade não são absolutos, mas ressalva a localização da diferença entre as duas modalidades de escrita. Para ela, a diferença reside no diálogo com as pessoas em campo e com os conceitos compartilhados por parte dos antropólogos, "ao contrário do autor de literatura 'pura' que, geralmente, vai criar sozinho os sentidos dos mundos que ele elabora" (CORDE, 2013, p. 26). O caso de Capitães da Areia é intrigante porque borra ainda mais as fronteiras entre literatura e etnografia. Zélia Amado disse que, para escrever o livro, Jorge Amado foi dormir com meninos e meninas de rua de Salvador (AMADO apud AMADO, 2008). Teria ele feito uma etnografia?

Independente da resposta a essa pergunta, nesse capítulo encontrei inspiração para pensar em questóes sobre a filiação na antropologia. No que consiste uma relação de filiação? O vínculo de filiação é universal? Como crianças lidam com pais, mães, cuidadores e cuidadoras? Essas perguntas sobre os pais e mães já foram feitas e refeitas de diferentes formas na elaboraçáo teórica do parentesco. Mas novas óticas e novos contextos sempre podem mirar as antigas perguntas de novos jeitos. As reflexôes que emergem da leitura de Capitães da Areia, bem como as contribuições da antropologia da criança, trazem desafios interessantes para repensar a família sob a ótica da criança. Pensar que as elas são agentes sociais, e, portanto, capazes de criar cultura, ideias e relações, estabelece novas formas de ver os fenômenos da vida social (BUSS-SIMÃO, 2009; COHN, 2005). Não seria diferente nos estudos sobre família ou de parentesco. É táo comum que pensemos nas diferentes formas que cuidadores e cuidadoras criam as crianças, mas quase não atentamos para o fato de que essas crianças também estáo criando famílias, parentes, culturas, cuidadores e cuidadoras.

A agência das crianças na criaçáo e rompimento de laços familiares é muito evidente em Capitães da Areia e coloca o questionamento sobre seu apagamento em vários trabalhos antropológicos sobre parentesco e família. A partir da experiência fictícia de crianças moradoras de rua de Salvador na década de 1930, podemos refazer as perguntas sobre filiação de uma outra maneira: como as crianças lidam com pais, mães, cuidadores e cuidadoras? Essa questão acompanhará o texto do início ao fim.

\section{Retrospecto teórico sobre parentesco}

Capitães da Areia traz histórias que negam a necessidade de vínculo com a família do pai e da mãe a priori. São histórias de crianças que viram 
os familiares morrerem, que foram abandonadas ou mesmo que fugiram de suas casas. Pedro Bala, o líder do grupo, nunca soube de sua mãe e teve o pai morto quando tinha cinco anos. Dora, aos treze anos, viu sua mãe morrer "de bexiga". Até tentou ser adotada por Dona Laura, para quem sua mãe trabalhou de lavadeira por muitos anos. Mas Dona Laura já estava com outra empregada trabalhando em sua casa e Dora se juntou às crianças do bando. A família de Sem-Pernas é desconhecida. Viveu na casa de um padeiro, a quem chamava de "padrinho" e que o surrava, até o dia que decidiu fugir. Muitas trajetórias diferentes se encontravam e se incorporavam ao bando dos Capitães da Areia. O que une todas elas é a ausência de pais, mães e demais familiares a partir de certo momento da infância. "Sem pai, sem mãe, sem mestre. Tinham de si apenas a liberdade de correr as ruas."

Para dar conta de uma constituição de parentesco que parte de uma ausência de pais ou mães é necessário fazer um pequeno retrospecto da história dos estudos em parentesco na antropologia. Descendência, filiação e parentesco são categorias analíticas que se confundem no início da disciplina. Para Morgan (1877), o parentesco e a descendência passam pela filiação, sendo possível classificar sociedades em que a descendência passa através da mãe (matrilinearidade) e em que a descendência passa através do pai (patrilinearidade). Para Radcliffe-Brown (1940), a descendência também tem um papel central, pois o parentesco é definido como uma relação entre pessoas que descendem de um antepassado em comum.

A elaboração dessas teorias do parentesco calcadas na descendência e suas regras coloca um debate interessante para a geração seguinte de antropólogos. A relação de filiação com a mãe é universal? Com Meyer Fortes (1953), a relação de filiação tanto com pai quanto com a mãe é alçada a uma condição universal com o conceito de filiação complementar. $\mathrm{O}$ autor diferencia filiação e descendência ao defender que mesmo que o ego não tenha antepassados comuns com a mãe ou com o pai, ele mantém a relação de filiação. Inspirado pela matemática, Edmund Leach (1961) vai no caminho oposto e defende que é possível que ego não tenha ligação nenhuma com o pai ou com a mãe, a depender das regras de descendência. Mas esses antropólogos clássicos ainda estáo longe de pensar teoricamente sobre crianças sem pai e sem mãe, ou seja, que não partem de uma relaçáo de filiação e nem de descendência.

David Schneider, em A Critique of the Study of Kinship (1984), levanta alguns argumentos interessantes que favorecem um distanciamento dos pressupostos dos estudos clássicos de parentesco. Schneider argumenta que todas essas descriçóes são feitas por meio de uma tradução, que usa um idioma do parentesco comum da disciplina. Entretanto, os antropólogos não questionam as limitaçóes desse idioma do parentesco na tradução de 
outras relaçôes. O problema, para Schneider, está justamente no fato de os antropólogos entenderem o parentesco como um fenômeno universal, com propriedades peculiares. Ao entender que todas as sociedades possuem um tipo de relação com essa substância comum, que chamamos de parentesco, a antropologia não questiona o uso desse idioma comum para a tradução. Esse idioma do parentesco é calcado na concepção de filiação como um produto de regras. A filiação e as regras de descendência são confundidas com a própria instituiçáo desse idioma do parentesco:

A distinção entre descendência e parentesco que é feita hoje começa pelo fato de que os termos foram primeiramente usados de forma intercambiável. Escritores de meados e do final do século dezenove (e do século vinte em alguns casos) frequentemente falaram de "parentesco traçado através do pai, mas não da máe" como patrilinearidade e "parentesco traçado apenas através da mãe" como matrilinearidade. ${ }^{3}$ (SCHNEIDER, 1984, p. 81)

Nesse idioma usado por antropólogos, o parentesco é derivado das regras de descendência. É a partir da identificação do pai e/ou da mãe de ego que é possível estabelecer de quem se é parente. A centralidade dada por categorias como pai e mãe parametriza outros sistemas de relaçóes e acaba por traduzi-los para esse idioma.

Nas décadas de 1970 e 1980, as antropólogas feministas já vinham construindo uma crítica à universalidade atribuída ao parentesco. A aversão a qualquer predeterminação biológica para a definição do que é ser mulher levou a reformulaçốes no conceito de cultura. O caráter transcultural do parentesco tem como pano de fundo as características biológicas de cada sexo, como a possibilidade de parir ou de amamentar. O questionamento da "mulher universal", determinada biologicamente, produziu um impacto grande em dicotomias nas quais a análise de parentesco se funda como natureza e cultura; esferas doméstica e pública; reproduçáo e produçáo. A agenda do abandono de certas premissas dos estudos de parentesco parte também dessas antropólogas. Entretanto, muitas dessas críticas não seguiram o mesmo caminho de Schneider, de abandono dos estudos de parentesco. Algumas delas optaram por continuar analisando os fenômenos antes estudados pelo domínio isolado do parentesco de forma integrada com um conjunto mais amplo de relaçóes: de gênero, econômicas, políticas etc. (FONSECA, 2003).

O conceito de relatedness, cunhado por Janet Carsten (2003), é uma tentativa de responder teoricamente a esse conjunto de fenômenos sem 
cair na oposição entre natural e biológico, que atravancou as discussóes teóricas por muito tempo, propondo um caráter mais processual dessas relaçóes. Carsten argumenta que o desenvolvimento do parentesco tem que ser compreendido no cotidiano das relaçóes. É justamente no compartilhamento de refeiçôes, nas trocas de presentes e afetos que as relaçóes de parentesco se constituem e reformulam. Essa perspectiva processual das constituiçóes de parentesco atenta para a ação dos parentes no cotidiano. A forma como os parentes levam suas relaçóes é um forte indicativo se estas vão prosperar ou não. Essa concepção aumenta o escopo de relações possíveis dentro daquilo que agrupamos como família e abre uma série de possibilidades para pensar a agência na filiação. Se as relaçóes de parentesco são formadas por açóes cotidianas, essas relaçóes passam a ser permeadas pelos interesses, pelos desejos, pelas emoçóes e pelas escolhas.

A crítica de Schneider pode ser extremamente importante para se conseguir enxergar o contexto das crianças do Capitães da Areia. Se todas as relações de parentesco são derivadas das regras de descendência, falar de parentesco entre crianças sem pai e sem mãe passa a ser um contrassenso. É preciso dar um passo atrás no idioma do parentesco para enxergar que pais e mães não são aprioristicamente fundamentais para o estabelecimento das relações das crianças. A desestabilização da distinção entre cultural e biológico feita pelas antropólogas feministas também é crucial para pensar o parentesco sob a ótica dos Capitães da Areia. Se não existe uma "mulher universal" que é responsável pela reprodução da família, tampouco existe uma criança universal que é cuidada por pais ou mães. Por fim, a contribuição do conceito de relatedness permite aventar a inclusão da agência das crianças na constituição cotidiana das suas relaçóes.

Este retrospecto dos estudos do parentesco abre margem para entender também como crianças podem escolher famílias. Em Families We Choose, Kath Weston (1997) apresenta configurações familiares de gays e lésbicas para defender uma dimensão eletiva das constituições familiares. Estudando contextos de famílias de gays e lésbicas em São Francisco, nos Estados Unidos, a autora identifica a importância da escolha na criação de laços entre homossexuais rejeitados ou não por suas famílias de origem. Weston defende a presença da escolha nos momentos em que se assume para a família a homossexualidade e quando os vínculos com essa família também são rompidos. A escolha também está presente nos momentos em que se constituem novos vínculos com cônjuges, filhos, filhas, amigos e amigas (que podem se tornar tios, tias, pais e mães). A autora apresenta um contexto em que a agência e as escolhas estão permanentemente constituindo famílias. Mas essas escolhas não são feitas apenas por gays e lésbicas. Também o são por seus pais, mães, irmãos, cônjuges e demais familiares. Mes- 
mo reafirmando esse papel da escolha, Weston tem a cautela de dizer que esta náo é feita descolada de um contexto de elementos e possibilidades com que as pessoas trabalham.

Descritivamente falando, as categorias de parentesco gay podem ser melhor classificadas como famílias que lutamos para criar, lutamos para escolher, lutamos para legitimar e - no caso da família biológica ou adotiva - lutamos para manter. Entre homens gays e lésbicas, existe um sentimento generalizado de que, como Diane Kunin coloca, "gays realmente têm que trabalhar para construir família”. Em certo sentido, pessoas de todas as identidades sexuais "trabalham" para construir família. ${ }^{4}$ (WESTON, 1991, p. 213)

Entender processo e agência nas constituiçóes de famílias é essencial para vislumbrar as possibilidades de família e filiação que Jorge Amado apresenta. Agora, posso entrar nos detalhes do capítulo "A família" para mostrar como o autor articula a agência das crianças no estabelecimento das configuraçôes familiares.

A capacidade de manejo das relaçóes familiares fica evidente desde o momento que identificamos que as fugas de casa e os rompimentos de vínculos são possíveis. O capítulo "A família" traz outros elementos para pensar essa possibilidade de criar, estabelecer e influenciar as relações de parentesco a partir de uma leitura alternativa da filiação. Náo pretendo absolutizar a noção de agência ou equipará-la a uma simples escolha descolada de seu contexto. É evidente o quanto pode ser perverso imputar totalmente à escolha de uma criança sua situação de abandono ou de morte dos parentes e a consequente ida para a rua. $\mathrm{O}$ intuito aqui é visibilizar que as crianças também possuem desejos, afetos e interesses nessa constituição de laços de parentesco e filiação.

\section{Filiação estratégica}

Agora é possível entrar mais propriamente no capítulo "A família". Ele se desenvolve com o estabelecimento de uma relaçáo de filiaçáo com uma das crianças dos Capitães da Areia. O menino adotado é Sem-Pernas, deficiente do grupo que nutre um ódio grande pelas pessoas de Salvador desde que foi espancado e humilhado por soldados da capital. A senhora que o adotou chama-se Dona Ester, moradora de uma grande casa em uma área nobre daquela cidade. Nesta seção, vou discutir essa situaçáo de adoçáo a partir da perspectiva da estratégia, elaborada por Pierre Bourdieu (2009) 
na análise de matrimônios de camponeses na França, aventando a possibilidade dela também estar presente na relação de filiação.

O capítulo começa com uma descoberta. O menino Boa-Vida ouve falar que em uma casa espaçosa e elegante de Salvador morava um colecionador de peças muito afortunado. Boa-Vida conta para Pedro-Bala, chefe do grupo, sobre a "sala entupida de ouro", de artigos do colecionador que descobriu. Sem-Pernas volta à casa no dia seguinte com a missão de roubar o ouro.

Muitas vezes já fizera aquilo: penetrar em casa de uma família como um menino pobre, órfão e aleijado e neste título passar os dias necessários para fazer um reconhecimento completo da casa, dos lugares onde guardavam os objetos de valor, das saídas fáceis para fuga. Depois os Capitães da Areia invadiam a casa numa noite, levavam os objetos valiosos [...]. (AMADO, 2008, p. 124)

No livro, a sobrevivência dos Capitáes da Areia depende de furtos, saques, doaçóes e esmolas. Saquear casas e revender seus bens preciosos era uma boa oportunidade. E Sem-Pernas era sempre o componente do grupo mais indicado para mapear essas casas saqueadas. Sem-Pernas sabia como ninguém fazer as caras que sensibilizavam os donos e donas das casas. A deficiência também era outro elemento que mobilizava essas famílias a adotarem-no ou permitirem sua estadia por alguns dias, tempo suficiente para repassar todas as informaçóes para os Capitães da Areia agirem. E esse era o propósito do menino quando bateu à porta de Dona Ester:

- Dona, eu não tenho pai, faz só poucos dias que minha mãe foi chamada pro céu. [...] Não tenho ninguém no mundo, sou aleijado, não posso trabalhar muito, faz dois dias que não vejo de comer e não tenho onde dormir [...].

- De que morreu sua mãe?

- Mesmo não sei. Deu uma coisa esquisita na pobre, uma febre de mau agouro, ela bateu a caçoleta em cinco dias. E me deixou só no mundo... Se eu ainda aguentasse o repuxo do trabalho, ia me arranjar. Mas com esse aleijão só mesmo numa casa de família... A senhora não tá precisando de um menino pra fazer compra, ajudar no trabalho de casa? Se tá, dona...

E como o Sem-Pernas pensasse que ela ainda estava indecisa, completou com cinismo, uma voz de choro:

- Se eu quisesse me metia aí com esses meninos ladrão. Com 
os tal de Capitães da Areia. Mas eu não sou disso, quero é trabalhar. Só que não aguento um trabalho pesado. Sou um pobre órfão, tou com fome... (AMADO, 2008, p. 120)

A abordagem de Sem-Pernas sensibiliza Dona Ester. Apresentar-se como uma criança sem familiares, com fome e sem nenhuma possibilidade de sobreviver mobiliza sentimentos de condescendência de moradores e moradoras de Salvador. Por ter uma deficiência, Sem-Pernas coloca que só conseguiria sobreviver em uma "casa de família". Joga ainda com a possibilidade de ser mais um dos Capitães da Areia e de colocar em perigo as propriedades e vidas das pessoas com essa decisão. A conversa se completa com a realizaçáo de uma coincidência e do início da construçáo de relaçáo entre os dois:

Depois perguntou como ele se chamava e o Sem-Pernas deu o primeiro nome que lhe passou pela cabeça:

- Augusto... - e como repetia o nome para si mesmo, para não se esquecer que se chamava Augusto, não viu no primeiro momento a emoçáo da senhora, que murmurava:

- Augusto, o mesmo nome...

Disse em voz alta, porque agora o Sem-Pernas olhava seu rosto emocionado:

- Meu filho também se chamava Augusto... Morreu quando tinha assim o seu tamanho... Mas entre, meu filho, vá se lavar para comer. (AMADO, 2008, p. 122)

Pronto. A situação está desenhada. Dona Ester reconhece naquele menino que bateu em sua porta o filho que houvera perdido. Assim, abre a sua casa e o adota como filho. Oferece para Sem-Pernas o quarto, refeiçóes diárias e até o uniforme de marinheiro que tinha sido de Augusto. Após essa cena, Dona Ester passa a chamar Sem-Pernas de "filho" até o fim do capítulo, localizando-o dentro da família.

Mas de que forma é possível entender essa situação sob a ótica das teorias de parentesco? Em primeiro lugar, é importante entender o que motivou e orientou Dona Ester e Sem-Pernas a tal situaçáo. A motivação de Sem-Pernas é mais evidente nesse início de capítulo. O menino queria saquear uma sala cheia de ouro da casa de um colecionador rico. Essa situação remete às estratégias no campo do parentesco. Estudando as regras e dotes matrimoniais entre camponeses, Pierre Bourdieu identifica, em $O$ senso prático ([1980] 2009), que as regras que estabelecem o parentesco são a todo tempo conformadas por interesses. A busca por manter ou aumen- 
tar poderes e privilégios alimentam estratégias não expressamente ditas, conformando uma economia de trocas matrimoniais. Na prática, as regras do matrimônio são instrumentalizadas por esses interesses. Podemos fazer um paralelo com a forma como Sem-Pernas instrumentaliza a filiação. A tentativa de Sem-Pernas de estabelecer novos vínculos familiares e ser adotado é totalmente orientada por interesses. Para alcançá-los, o menino precisa se mostrar um bom jogador no manejo das regras de adoção.

Mas com o que Sem-Pernas está jogando? O que Sem-Pernas possui para oferecer em troca do socorro de Dona Ester? Os elementos que Sem-Pernas usa para sensibilizar a dona da casa, e que são recorrentemente usados pela personagem, permitem algumas reflexóes. Sem-Pernas joga com vários elementos que o vitimizam em meio a uma realidade cruel das ruas. O menino se apresenta como uma criança "aleijada", "pobre”, "órfâ" e que, caso não fosse adotado por uma família, morreria ou entraria para um bando de crianças saqueadoras e perigosas.

Esse jogo revela um pouco sobre a dinâmica da adoção de crianças. Cláudia Fonseca, em Caminhos da adoção, diz: "Além do prestígio advindo de socorrer os necessitados, a mãe adotiva se beneficia teoricamente de todas as vantagens que acompanham a maternidade, em particular a devoção eterna dos filhos" (FONSECA, 2006). A adoção possui benefícios também para quem adota. Como Dona Ester se sentiria deixando uma criança "pobre", "órfâ" e "aleijada" na rua? Ter filhos ou filhas para cuidar já é um benefício da adoção, bem como socorrer quem precisa de ajuda confere ao adotante prestígio e um alívio do remorso. Portanto, existe uma economia da culpa e do cuidado, a qual Sem-Pernas manipula. Quanto mais triste for a história contada pelo menino, maior o remorso e vontade de cuidado de Dona Ester e maior a possibilidade de ele ser adotado.

Essa economia da culpa e do cuidado movimenta as trocas entre os dois. Do lado de Sem-Pernas, o interesse em saquear uma sala cheia de ouro, além de ter uma boa cama para dormir e refeições para fazer durante alguns dias. Do lado de Dona Ester, a possibilidade de confortar uma perda de um elemento da estrutura familiar e ao mesmo tempo evitar o sentimento da culpa por deixar um menino pobre e deficiente viver na rua ou com os Capitães da Areia. Trocam-se o remorso e a culpa por alguns dias de "casa de família”. A estratégia de ser adotado é bem-sucedida. A ausência, a priori, de pai ou mãe é um pontapé para o início de uma nova relação. É inegável que Sem-Pernas teve um agenciamento na constituição dessa adoção. ${ }^{5}$ 


\section{Trocando sentimentos}

A história entre Dona Ester e Sem-Pernas evidentemente não acaba por aí. Nesta seção, sairemos do campo das estratégias para discutir a filiação a partir das trocas e sua relação com as emoçóes. A reciprocidade também pode ser um conceito importante para entender o desenrolar da história de Sem-Pernas com Dona Ester e, consequentemente, para as reflexóes sobre as relaçóes de filiação. Nessa parte da história, as trocas entre mãe e filho mexem com os sentimentos das personagens, complexificando ainda mais a trama.

A primeira etapa do plano dos Capitães da Areia estava concluída. Sem-Pernas fora adotado por Dona Ester. Mas o plano não se interrompe nessa etapa. Agora, o menino deve esperar a família se acostumar com ele para, então, ter uma oportunidade de abrir a porta da casa. Assim, os Capitães da Areia podem entrar e saquear aquilo que acharem valioso. Tudo corre bem na primeira etapa. Entretanto, algo de inesperado mexe com Sem-Pernas. $\mathrm{Na}$ experiência do menino, todas as famílias que, por remorso, o adotaram, se arrependeram em seguida. Ao adotá-lo, Dona Ester faz algo que ninguém nunca tinha feito: ela o vestiu, o alimentou, deu beijos, abraços e até uma bicicleta. "Desta vez não o deixaram na cozinha com seus molambos, não o puseram a dormir no quintal. Deram-lhe roupa, um quarto, comida na sala de jantar" (AMADO, 2008, p. 125).

$\mathrm{O}$ inesperado surge do que a troca revela. A reciprocidade de Dona Ester mostra que ela o recebeu como filho. Como na fórmula de Marcel Mauss (1925), o "dar um filho" por parte de Sem-Pernas conta com um receber a dádiva e retribuir em forma de "ser mãe". E recusar a receber "equivale a declarar guerra, é recusar a aliança e a comunhão" (MAUSS, 2003, p. 202). Colocar o menino para dormir no quintal é o mesmo que abrigá-lo, mas não que criar o vínculo de filiação. Após tantas experiências, Sem-Pernas não esperava ser recebido como filho.

A possibilidade de comungar com quem, a princípio, iria guerrear mexe com os sentimentos de Sem-Pernas. Para o plano dar certo, os Capitáes da Areia contavam com o ódio de Sem-Pernas aos seus oponentes. O menino só seria capaz de saquear quem o adotara por sentir um ódio profundo. A retribuição de Dona Ester em forma de refeiçóes, roupas, quarto e afeto coloca em xeque seus sentimentos. Na descrição genial de Jorge Amado:

Para Sem-Pernas, elas [as famílias] o acolhiam de remorso. Porque o Sem-Pernas achava que eles eram todos culpados da situação de todas as crianças pobres. E odiava a todos, com um ódio profundo. Sua grande e quase única alegria era calcular o 
desespero das famílias após o roubo, ao pensar que aquele garoto esfomeado a quem tinham dado comida fora quem fizera o reconhecimento da casa e indicara a outras crianças esfomeadas onde estavam os objetos de valor. Mas desta vez estava sendo diferente. [...] E, de súbito, tem medo de que nesta casa sejam bons para ele. Não sabe mesmo por quê, mas tem medo. E levanta-se, sai do seu esconderijo e vai fumar bem por baixo da janela da senhora. Assim verão que ele é um menino perdido, que não merece um quarto, roupa nova, comida na sala de jantar. Porque se esse ódio desaparecer, ele morrerá, não terá nenhum motivo de viver. (AMADO, 2008, p. 125)

O amor de Dona Ester fica evidente nos presentes que dá a Sem-Pernas. A possibilidade de rever os próprios sentimentos amedronta o menino. A relação entre as trocas e os sentimentos é estudada por Maria Cláudia Coelho. A autora reflete sobre a ambiguidade da obrigatoriedade e da espontaneidade da dádiva, apontada por Mauss, para discutir o local do afeto nas trocas de presentes. Coelho recolheu depoimentos que demonstraram incômodo na obrigação de dar presentes em datas comemorativas (aniversários, Dia das Mães, Natal etc.): "Em alguns depoimentos, dar presentes sob a égide de uma obrigação aparece quase como uma contradição em relação à natureza do presente - expressar afeição" (COELHO, 2003, p. 343). As trocas são entendidas como uma linguagem de expressão das emoções.

As dádivas de Dona Ester são uma linguagem que expressa como ela se sente em relação ao seu filho. As trocas são uma expressão de afeto e amor e, como linguagem, revelam a Sem-Pernas essa afeição de uma mãe. Mas, como toda dádiva, a espontaneidade da demonstração do afeto contém em si o desejo de reciprocidade e a obrigação da retribuição. Essa demonstração de afeto interpela o menino a amá-la como mãe e isso causa medo em Sem-Pernas. O medo é tanto que o menino tenta desfazer a troca, mostrando de toda forma que nunca foi o filho de Dona Ester. Por isso, Sem-Pernas torce para que Dona Ester descubra que é tudo uma farsa e pare de tratá-lo como o filho que se tornara. $\mathrm{O}$ menino tenta retribuir a expressão do amor de mãe mostrando que não existe filiação nenhuma. Mas de nada adianta. Sem-Pernas já se tornou seu filho. Ele não odeia mais Dona Ester. Seu ódio por ela foi trocado por outro sentimento.

\section{Filiação e os dilemas da estratégia afetada}

Mas, à medida que Sem-Pernas recebe o carinho de mãe de Dona Ester, a situação vai se tornando um dilema. A estratégia é interpelada pelo afeto 
de Dona Ester e, sem que ele esperasse, o menino se percebe inserido em uma família. Porém, Sem-Pernas náo pode ser da família de Dona Ester e fazer parte dos Capitães da Areia ao mesmo tempo. Nesta seção, retomarei os conceitos de relatedness (CARSTEN, 2003) e de famílias que escolhemos (WERSTON, 1997) para interpretar o desfecho desse conflito vivido por Sem Pernas.

Como na perspectiva de Carsten, o laço familiar entre os dois surge de um processo. À medida que Dona Ester trata Sem-Pernas no cotidiano como um filho, essa relação vai de fato se constituindo em relatedness. Esse processo vai transformando a relaçáo entre Sem-Pernas e Dona Ester, criando a possibilidade de afeto sincero. Assim como o livro Capitäes da Areia mostra que crianças podem romper laços com pais e máes, a obra traz o caso de uma criança que cria, junto de uma senhora, uma nova relação de mãe e filho. No romance de Jorge Amado, tornar-se filho é um processo concomitante com tornar-se mãe.

A continuidade do plano dos Capitães da Areia envolve trair sua própria mãe. Como poderia roubar a própria mãe? Como poderia fugir de quem tanto lhe dava afeto? Com certeza, executar o restante do plano não era mais desejo do menino. Mas abandonar as outras crianças não era menos doloroso:

E se para alguém o Sem-Pernas abria exceção no seu ódio, que abrangia o mundo todo, era para as crianças que formavam os Capitães da Areia. Estes eram seus companheiros, eram iguais a ele, eram vítimas de todos os demais, pensava o Sem-Pernas. $\mathrm{E}$ agora sentia que os estava abandonando, que estava passando para o outro lado. [...] Náo, ele náo os trairia."(AMADO, 2008, p. 130)

O desejo de não trair Dona Ester bate de frente com a profunda identificação de Sem-Pernas com as crianças do bando Capitães da Areia. Muitas vezes no romance, Sem-Pernas ridiculariza, bota apelidos e até briga com os outros do bando (AMADO, 2008, p. 37). Mas o menino tem uma profunda identificação com todas essas crianças, mesmo com aquelas com que briga. Assim como ele, essas crianças "eram vítimas de todos os demais". Dormem no trapiche juntas por serem todas abandonadas. E lá as crianças comem, exibem as roupas novas, transam, brigam, elaboram planos para saques e para salvar umas às outras do reformatório. Sem-Pernas gosta de Professor, respeita Pedro Bala e nunca pretendeu trair as regras do grupo.

A partir do momento que Sem-Pernas passa a ter uma máe, ele se distancia das outras crianças abandonadas. Não é mais uma criança sem pai e sem mãe. No momento em que o afeto e as trocas entram na relação dele 
com Dona Ester, as estratégias se confundem com a afeição, e o dilema passa a envolver também seus afetos com os Capitães da Areia. A dúvida de a quem se deve ser mais fiel - se à sua mãe ou aos Capitáes da Areia - toma conta de Sem-Pernas. Assim como as famílias na etnografia de Werston (1997), Sem-Pernas se vê obrigado a escolher sua família.

Lembrou-se que das outras vezes, quando dava o fora de uma casa para ela ser assaltada, era uma grande alegria que o invadia. Desta vez não tinha alegria nenhuma. Seu ódio para todos não desaparecera, é verdade. Mas abrira uma exceção para gente daquela casa, porque dona Ester o chamava de filho e o beijava na face. O Sem-Pernas luta consigo mesmo. Gostaria de continuar naquela vida. Mas que adiantaria isso para os Capitães da Areia? E ele era um deles, nunca poderia deixar de ser um deles porque uma vez os soldados o prenderam e o surraram enquanto um homem de colete ria brutalmente. $\mathrm{E}$ o Sem-Pernas se decidiu. Mas olhou com carinho as janelas do quarto de Dona Ester e ela, que o espiava, notou que ele chorava:

- Está chorando, meu filho? - e desapareceu da janela para vir para junto dele.

$[\ldots]$

- Não chore por sua mãe. Agora você tem outra mãezinha que lhe quer bem e fará tudo para substituir a que você perdeu... [...] Dona Ester beijou na face onde as lágrimas corriam:

- Não chore, que sua mãezinha fica triste.

Então os lábios de Sem-Pernas se descerraram e ele soluçou, chorou muito encostado ao peito de sua mãe. E enquanto a abraçava e se deixava beijar, soluçava porque a ia abandonar e, mais que isso, a ia roubar. E ela talvez nunca soubesse que o Sem-Pernas sentia que ia furtar a si próprio também. Como não sabia que o choro dele, que os soluços dele eram um pedido de perdão. (AMADO, 2008, p. 131)

O afeto relocaliza Sem-Pernas, tornando a estratégia anterior sem sentido. A estratégia inicial de roubar uma casa vira o dilema de roubar a própria mãe. Contudo, o menino escolhe continuar sendo um dos Capitães da Areia. Após pouco mais de uma semana na casa de Dona Ester, Sem-Pernas abre a casa para os Capitães da Areia roubarem as obras mais valiosas. Sem-Pernas recusa sua parte no dinheiro do roubo e, no final do capítulo, vive o luto de ter perdido a mãe. Dona Ester chega a procurar o jornal da cidade para dar a notícia de seu filho desaparecido que buscava. Tudo isso antes 
de descobrir o roubo. O romance de Jorge Amado segue daí. O capítulo se encerra, mas não se encerram as histórias das crianças sem pai e sem mãe.

\section{Conclusão}

A leitura de Jorge Amado sugere uma outra percepção sobre o papel das crianças no parentesco e na família. Crianças podem romper vínculos familiares. Crianças podem criar pais e mães. Crianças podem ter afeto mesmo sem pai e sem mãe. A vivência de Sem-Pernas com Dona Ester pode nos ajudar a refletir sobre contextos mais amplos de produção de relações de adoção. Também enfocando as possibilidades de agência da criança na filiação e na adoção, Claudia Fonseca nos descreve a prática da "autocirculação de crianças". A autora mostra que a guarda de filhos não é uma decisão apenas de adultos. Crianças também escolhem morar com o pai ou com a tia, fogem de casa, chantageiam e fazem uma série de outras práticas para influenciarem nas decisóes de guarda dos adultos. Sobre esta prática, a autora escreve:

Fica claro que no caso de crianças maiores, a decisão dos adultos (inclusive o julgamento legal) tinha efeito limitado. Anexadas a dois dossiês, achamos queixas semelhantes: o adulto que ganhou o processo (uma vez com o apoio, outra com a oposição do menor) não conseguiu manter o menor sob controle, pois este fugiu para lugar desconhecido pouco tempo depois do julgamento. Havia discrepância evidente entre a visão legal do menor (sujeito até 21 anos ao pátrio poder de algum adulto) e a realidade de uma pessoa em plena atividade econômica a partir da adolescência. (FONSECA, 2006, p. 72)

Essa perspectiva de visibilização da ação das crianças nos laços familiares e de parentesco estão em consonância com os avanços que a antropologia da criança tem feito. Márcia Buss-Simão (2009), em Antropologia da criança: uma revisão da literatura de um campo em construção, apresenta as divergências entre abordagens clássicas da antropologia e o olhar da chamada "nova" antropologia da criança. A autora demonstra que as crianças estão presentes na antropologia desde o seu início. Entretanto, nos estudos clássicos, as crianças tendem a náo ser percebidas enquanto atores e atrizes sociais. Na "nova" Antropologia da Criança, estas sáo percebidas enquanto capazes de engendrar mudanças, interpretar os contextos, reproduzindo e recriando as relaçóes com adultos e entre elas próprias. As crianças deixam de ser receptáculos de uma socialização unidirecional e passam a ser produtoras de culturas que se relacionam com os adultos, também desempenhando um papel socializador em relação a estes. 
Junto com o reconhecimento da ação de crianças nas reconfigurações familiares, Capitães da Areia traz a diversidade de motivaçóes que uma criança pode ter nessa construção da família e do parentesco. O romance permite refletir que as estratégias e interesses por poder, bens e privilégios não estão fora do horizonte das crianças na relação de filiação. Observar como as crianças manipulam e chantageiam pais, mães, avós, cuidadores e cuidadoras a partir do conceito de estratégia pode revelar elementos interessantes sobre essas relaçóes.

Ao mesmo tempo, imputar às crianças somente o papel de frias jogadoras nas suas relações de filiação pode ocultar um elemento fundamental dessa relação: a expressão do afeto. Na história de Dona Ester e Sem-Pernas, o afeto confunde as estratégias, embaça os interesses e reconduz a relação de filiação. E o afeto é principalmente descrito como trocas e dádivas. A cama, as refeições, os beijos e abraços formam a linguagem do afeto que transformam o local de Sem-Pernas no mundo. Essa linguagem é formada por um processo ao mesmo tempo espontâneo e obrigatório que consiste em dar, receber e retribuir afeto. Tornar-se filho ou filha é um processo assim como tornar-se mãe ou pai.

A ideia processual da constituição das relações de filiação rompe com os universalismos das regras elaboradas pelos clássicos. Nega-se o processo de constituição desses vínculos quando entendemos a filiação como simplesmente derivada de patrilinearidades, matrilinearidades ou bilateralidades. A noção de relatedness de Janet Carsten permite inserir as crianças como atores e atrizes importantes na constituição destes laços à medida que reconhece esta relação como processo. A autora quebra, assim, dicotomias como cultura/natureza para entender o laço familiar em sua especificidade e em seu cotidiano. Reconhecer que as crianças constroem a filiaçáo faz parte do mesmo movimento de reconhecer a diversidade de formas que essa relação pode assumir, ou mesmo inexistir.

As crianças sem pai e sem mãe da história criaram uma série de relaçôes de filiação pela cidade e induziram um processo de socialização para adultos e para elas próprias. À medida que batia nas portas das casas das senhoras para ser adotado, Sem-Pernas aprendia as melhores formas de jogar com a economia da culpa e do cuidado para conseguir seus objetivos. Adultos lidaram com essas adoções de maneiras diferentes e aprenderam também com essas situações. Dona Ester também já tinha desenvolvido algum aprendizado com seu primeiro filho, Augusto, sobre como ser mãe. Portanto, a relação de filiaçáo de Sem-Pernas com Dona Ester é uma construção conjunta, que parte de experiências anteriores das duas personagens e geram novas aprendizagens sobre filiaçáo para ambos. $\mathrm{O}$ processo de construção desse laço familiar - relatedness - é uma coprodução de afeto, aprendizados, de estratégias e demais possibilidades de ação de mãe e filho. 
O que a história de Sem-Pernas com Dona Ester nos mostra é que as agências das crianças são permeadas por estratégias econômicas, afetaçóes e cuidados. Muito ainda precisa ser entendido sobre os desejos e interesses das crianças em relação a seus familiares. Podemos pensar que elas constroem essas relações também e seus incômodos e desejos podem levá-las a muitas ações e estratégias. No romance de Jorge Amado, a troca cotidiana de afetos mudou os planos de Sem-Pernas, ou, pelo menos, os termos pelos quais ele foi pensado. Quem sabe olhando mais para as crianças sem pai e sem mãe podemos refletir como é ser pai e ser mãe por outras perspectivas?

\section{Notas}

1. Este artigo foi desenvolvido a partir do trabalho de conclusão da disciplina Organização Social e Parentesco ministrada pelo professor Wilson Trajano e pela professora Andréa Lobo no PPGAS/UnB. Posteriormente, o texto recebeu contribuiçôes durante a disciplina de Oficina de Escrita Etnográfica ministrada pela professora Soraya Fleischer no mesmo departamento. Agradeço bastante às contribuiçôes das professoras e colegas na elaboração deste texto.

2. Estas informaçôes foram retiradas da cronologia da vida de Jorge Amado do final da edição da Companhia das Letras de Capitáes da Areia.

3. Tradução livre: "The distinction between descent and kinship which is made today starts with the fact that the terms were at first often used interchageably. Writers in the mid - and late nineteenth century (and into the early twentieth century in some cases) often spoke of 'kinship being traced through the father but not the mother' for patriliny and 'kinship traced through the mother only' for matriliny".

4. Tradução livre: "Descriptively speaking, the categories of gay kinship might better be labeled families we struggle to create, struggle to choose, struggle to legitimate, and - in the case of blood or adoptive family - struggle to keep. Among gay men and lesbians, there is the pervasive sense that, as Diane Kunin put it, 'gay people really have to work to make family'. In a sense, people of all sexual identities 'work' to make kinship".

5. Notar que uma criança faz uso de estratégias para tornar-se filha pode gerar questionamentos sobre outros agenciamentos. É possível levantar questôes sobre agenciamento, economia da culpa e estratégia das crianças. Com que joga uma criança na relação com seus pais e mães? Que estratégias são usadas por filhos e filhas para alcançar interesses? Como as vontades das crianças afetam a relação de filiação? Todas essas questôes emergem da possibilidade de aventarmos uma filiação estratégica. 


\section{Referências bibliográficas}

AMADO, Jorge. Capitães da Areia. São Paulo: Companhia das Letras, 2008.

BOURDIEU, Pierre. O senso prático. Petrópolis, RJ: Vozes, 2009.

BUSS-SIMÃO, Márcia. Antropologia da criança: uma revisão da literatura de um campo em construção. Revista Teias, v. 10, n. 20, jul. 2009.

CLIFFORD, James; MARCUS, George. Writing Culture: the poetics and politics of ethnography. Berkeley/Los Angeles/London: University of California Press, 1986.

COELHO, Maria Claudia. Dádiva e emoção: obrigatoriedade e espontaneidade nas trocas materiais. RBSE, João Pessoa, v. 2, n. 6, p.335-350, GREM. 2003. COHN, Clarice. Antropologia da criança. Rio de Janeiro: Jorge Zahar Ed., 2005. CORDE, Marine Lila. A articulação entre objetividade e subjetividade nos textos antropológicos: contribuição da escrita literária para a construção de saberes antropológicos. Revista de Ciências Sociais, Fortaleza, v. 44, n. 2, p. 12-30, jul./dez. 2013.

CARNSTEN, Janet. Cultures of Relatedness. New approaches on the study of kinship. University of Edinburgh: Edinburgh, 2003.

FONSECA, Cláudia. Os caminhos da adoção. São Paulo: Cortez, 2006.

De afinidades a coalizóes: uma reflexão sobre a "transpolinização" entre gênero e parentesco em décadas recentes da antropologia. ILHA - Revista de Antropologia, Florianópolis, v. 5, n. 2, p. 5-31. 2003.

FORTES, Meyer. The Structure of Unilineal Descent Groups. American Anthropologist. 1953.

LÉVI-STRAUSS, C. As estruturas elementares do parentesco. Petrópolis: Vozes, 1978.

LEACH, Edmund. Repensando a antropologia. São Paulo: Perspectiva, 1974.

MAUSS, Marcel. Sociologia e antropologia. Cosac Naify: São Paulo, 2003.

MORGAN, L. H. Ancient Society: researches in the lines of human progress from savagery through barbarism to civilization. Nova York: Holt Press, 1877.

RADCLIFFE-BROWN, A. R. Sistemas africanos de parentesco e casamento - Introdução. In: MELATTI, J. C. (Org.). Radcliffe-Brown. São Paulo: Ática, 1978.

SCHNEIDER, David. A Critique of the Study of Kinship. The University of Michigan Press, 1984.

WESTON, Kath. Families We Choose: lesbians, gays, kinship. Nova York: Columbia University Press, 1997.

\section{autor Gustavo Belisário d'Araújo Couto}

É mestrando no departamento de Pós-Graduação em Antropologia Social da UnB, bolsista CNPq. 